\title{
Sustainable Tourism Model Based on Environmental Wisdom in Penglipuran Tourism Village, Kubu Subdistrict, Bangli
}

\author{
A.A. Rai Sita Laksmi ${ }^{1}$ and A. A. Gede Oka Wisnumurti ${ }^{2}$ \\ \{sitalaksmi08@gmail.com¹ and okawisnumurti@gmail.com² \\ Universitas Warmadewa, Denpasar-Bali, Indonesia
}

\begin{abstract}
This article aims to find out the form and implementation of sustainable tourism based on environmental wisdom. This study is designed using a qualitative method. There are two results found. First, the form of sustainable tourism based on environmental wisdom includes (1) the form of policy contained in the vision of the tourism village management agency, (2) the form of the organizational structure of the management institution that collaborates indigenous people and villagers, and (3) the form of distribution of retribution proceeds determined through the Decree of the Level II Regional Chief of Bangli. Second, the implementation of sustainable tourism based on environmental wisdom includes (1) conservation of the physical environment, (2) biotic (forest) environmental conservation, and (3) tourism business development. Third, the sustainable tourism model based on environmental wisdom is a model of tourism village development with collaboration between local community elements.
\end{abstract}

Keywords: Environmental wisdom; sustainable tourism; tourism village

\section{Introduction}

Culture and tourism have always been inextricably linked [1]. Tourism is a sector with significant economic relevance in several countries [2]. Tourism contributes enormously towards the economic development of host countries [3]. Tourists being consumers would prefer to visit a certain destination where they believe they can easily derive satisfaction without much effort [4]. Tourism has shown sustainable growth over the last few decades, leading to the development of multiple tourism-related industries [5]. Sustainable development is increasingly becoming a priority issue in tourism development in the modern world [6]. Tourism has repeatedly been reported as a powerful activity that can have significant impacts on a nation, often concerning a country's economy, society and culture, and environment [7]. The senior population is of interest to the tourism industry because of its growing size and increasing participation in travel activities [8]. The anticipated experience is marked by the ways in which ecotourism companies employ ecotourism ideology for their marketing, and the lived experience is marked by tourists after their interaction with the place (landscape) [9]

Conventional tourism trends that are oriented towards large numbers (mass tourism), using strategic places, and requiring large amounts of land have led to degradation of sociocultural values, and pollution and environmental damage [10] In reaction to the negative impacts of conventional tourism development, the emergence of the thought of alternative tourism development that supports environmental preservation and improvement of community welfare, namely sustainable tourism. According to Federation of Nature and 
National Parks (1993), sustainable tourism is all tourism development, management and activities that maintain environmental, social, economic, and welfare integrity of existing natural and cultural resources for a long period of time [11].

In Bali, sustainable tourism development discourses are contained in Government Regulation Number. 2 of 2012 which states that tourism development in addition to improving community welfare is also directed to preserve the natural and cultural environment in a sustainable manner. In preserving the environment, Balinese people have thoughtful and goodvalue ideas that are embedded and followed by the community called environmental wisdom. According to Wardi [12] environmental wisdom is part of cultural wisdom in the context of conservation. The form of environmental wisdom can be reflected in cultural heritage [13].

The development of tourism that is oriented towards environmental preservation and improving the welfare of the community based on the cultural values possessed can be observed in Penglipuran Village, Kubu Subdistrict - Bangli Regency. This village is a Bali Aga village which is developed into a tourist village. As stated by the custom village head of Penglipuran 'I Wayan Supat' (August 18th, 2018) "The Penglipuran community does not create tourism objects, but maintains cultural heritage based on existing values so that it becomes a tourist attraction."

Based on the background above the study entitled "Sustainable Tourism Model Based on Environmental Wisdom in Penglipuran Tourism Village, Kubu Subdistrict, Bangli" is very interesting to do. The formulations of the problem in this study are (1) how is the form of sustainable tourism based on environmental wisdom? (2) How is the implementation of sustainable tourism based on environmental wisdom? and (3) how is the sustainable tourism model based on environmental wisdom in Penglipuran Tourism Village? This article aims to find out the form and implementation of sustainable tourism based on environmental wisdom.

Theoretically, this research can provide benefits for scientific development related to sustainable development based on environmental wisdom. Practically, this research can provide benefits for the government, tourism actors, and the community in determining policies in sustainable tourism management based on environmental wisdom. The theory used is ecocentric theory (Deep Ecology) by Arne Naess and the theory of power and knowledge by [14].

This study is designed using a qualitative method of collecting descriptive data in the form of written and oral words obtained from the community in preserving the environment. The location of this study is Penglipuran Village, Kubu Subdistrict, Bangli Regency that is a Bali Aga Village developed into a tourist village. Data collection is done by observation, interviews, and document study. Data analysis was carried out qualitatively through three activities, namely data reduction, data presentation, and conclusion.

\section{Results and Discussion}

Sustainable tourism is essentially concerned with ensuring that the natural, social and cultural resources that are used for tourism development in generations are now preserved for future generations [15]. The basic principles of developing sustainable tourism are (1) upholding the quality of the tourist experience, the lives of local people in a better direction, and the quality of a well-maintained physical environment; (2) sustainability of natural resources, local culture, and tourist satisfaction; and (3) a balance between the needs of tourists, the physical environment and the interests of local communities [16]. 
In realizing sustainable tourism, it cannot be separated from local wisdom relating to the environment (environmental wisdom). According to Wardi, environmental wisdom is a cultural value that reflects the success of human adaptation in interacting with the natural environment which is carried out consciously and wisely in an effort to maintain and improve the quality of survival while maintaining stable environmental conditions and functions [12].

This discussion will describe the form, implementation and model of sustainable tourism based on environmental wisdom in the Penglipuran tourism village, Bangli.

\subsection{Form of Sustainable Tourism Based on Environmental Wisdom}

Penglipuran Village is designated as a tourist village based on the Decree of Bangli Level II Regional Head Number 115 of 1993 concerning the establishment of tourist objects in Bangli Level II Regions. Considering that tourist visits are increasing and requiring more professional management, then on May 1st, 2012 Penglipuran Traditional Village formed a special institution to manage a tourist village named Penglipuran Tourism Village Management Agency. The form of sustainable tourism based on environmental wisdom in Penglipuran Village can be observed in the direction of the management institution's policy, the organizational structure of the management institution, and the distribution of the results of the levy as follows:

First, the direction of the management agency's policy. In the development of Penglipuran tourism village, the management agency determines the direction of the policy contained in the vision of the management institution, namely making the tourism village based on community, culture, and environmentally sound. To realize this vision, the management agency determines the mission of increasing community participation, improving skills, improving the welfare of the community, preserving art and culture, and preserving the environment with the concept of Tri Hita Karana.

Second, the organizational structure of the management institution. In the development of tourism villages, local communities, namely indigenous village head, are involved in the organizational structure of the management institution as the Board of Trustees. The management agency is led by a manager who is collectively responsible to the Penglipuran Customary Village through indigenous village head (prajuru adat).

Third, division of management results. Based on the Decree of the Level II Regional Chief of Bangli No. 116 of 1993 concerning the appointment of the Penglipuran Traditional Village as a tourist collection retribution officer, it is stated that the customary village is given $40 \%$ of the proceeds from retribution and the remaining $60 \%$ is for the government.

The explanation above shows that the form of tourism in Penglipuran Village is very concerned about the harmonization of the environment, the social life of the community, and the improvement of the welfare of the community. This is in line with ecocentric theory which seeks human welfare and balance between individuals and the overall interests in the ecosystem. The Penglipuran Village Tourism form is also in line with the view of Word Tourism Organitation that sustainable tourism development must meet the basic requirements, namely ecoloycal sustainability, economic sustainability, and social and cultural sustainability [11].

\subsection{Implementation of Sustainable Tourism Based on Environmental Wisdom}

Penglipuran village has a unique environment which is used as a potential for tourism village development. To maintain the sustainable quality of the environment, natural resources and culture of local communities, as well as maintaining environmental balance, the Penglipuran community implements cultural values embedded in people's lives. The 
implementation of sustainable tourism based on environmental wisdom includes physical environmental (abiotic) conservation, forest conservation (biotic), and the tourism business development based on local resources.

First, conservation of the physical environment. Penglipuran Village, located at a distance of $45 \mathrm{~km}$ from the city of Denpasar or $5 \mathrm{~km}$ from the city of Bangli, has an area of $112 \mathrm{ha} .9$ ha are settlements and 4 ha are holy places. Judging from the physical environment, Penglipuran Village has a unique pattern of village spatial planning and residential patterns that become a tourist attraction. The layout of the village uses a linear pattern that is the central axis as the center, extending from north to south dividing the settlement into two parts facing each other that is west and east. The structure of the village pattern shows the tradition of megalithic buildings. The residential pattern consists of 76 yards with the same structure and entrance (angkul-angkul). Both the village and residential patterns are based on the concept of dualism (rwa bineda) and the concept of Tri Mandala.

To protect the physical environment, the community strives to conserve by providing a subsidy of 30.000 .000 each family to repair damaged buildings. This is intended to keep the building sustainable and can be enjoyed by tourists in a sustainable manner. That is, preservation in this case is not only intended to be "maintained" but to be the welfare of the community.

Second, forest conservation. Penglipuran village has 4 ha of timber forest and 45 ha of bamboo forest. Timber forests are located in the north and east of Penataran Temple. The most widely grown wood is Majegau wood which is the mascot of the province of Bali. The existence of timber forests is protected by traditional villages. The existence of timber forests is protected by traditional villages. In order to cut down trees, the people not only have to ask for permission from the traditional village head, but also through a religious ceremony in the case of asking permission from the God, the ruler of the forest. This is done so that the trees that are cut can be durable and not eaten by termites.

Bamboo forests are located in the north and west of Penglipuran Village. There are thirteen types of bamboo planted in Penglipuran Village, namely bamboo Jajang Aya, Jajang Bali, Jajang Panting, Jajang Taluh, Jajang Papah, Jajang batu, Tambang Gading, Tambang, Patung Buluh, Tali Suet, Tali Gading, and Ampel. Penglipuran Village also has rules for cutting bamboo. If there are people who cut bamboo, they must first determine a good day so that the bamboo is not damaged and dead.

Thus, it is clear that in Penglipuran Village there are beliefs and cultural values adhered to by the community in conserving forests. This is in accordance with what Wardi conveyed that environmental wisdom in the context of conservation is reflected in various forms of cultural values such as beliefs and rules or rules of customary law (awig-awig) [12].

Third, the development of tourism businesses. To absorb tourism activities, Penglipuran Village develops tourism businesses in accordance with the village's potential. These include lodging, food such as kelepon, sweet potato chips, sweet potato donuts; drinks like loloh cemcem, loloh kunyit, onion pearl tea; and bamboo handicrafts such as replica of Penglipuran houses, and bamboo woven. It means that Penglipuran Village has developed the potential of natural resources for the development of tourism villages and improved community welfare.

\subsection{The Model of Sustainable Tourism Based on Environmental Wisdom}

Penglipuran Village adheres to three social systems, namely the Ulu Apad system, customary village, and official village. Ulu Apad is a resident citizen of 76 people. Numbers 1 to 12 are called Jero Kancan Roras who are considered as village elders and numbers 13 to 76 are called palitan. Penglipuran village consists of one customary cummunity so that bendesa 
adat (traditional village head) is also as kelihan adat (customary village head). The official village consists of one environment led by the head of the environment/village. Ulu Apad, customary village, and official village are one unit that cannot be separated from each other and the three are involved in the development of Penglipuran Tourism Village.

The involvement of traditional villages in the development of tourism villages shows that traditional villages have the power to preserve the environment and develop natural resources that they possess. Therefore, the traditional villagers that know best or have the knowledge to manage the potential that exists for tourism village development. The Penglipuran community also has responsibilities compared to outside communities, because what is done in environmental conservation will affect their lives in a sustainable manner. The role of the Penglipuran Indigenous Village community in environmental conservation with the theory of power and knowledge is where power is not only in the state (government) but also in society. As Foucault said that power does not only come from the authorities but spreads everywhere.

Thus, the sustainable tourism model based on environmental wisdom in Penglipuran Tourism Village is a model of tourism village development by considering environmental sustainability, community social life, and sustainable welfare with collaboration between local community elements such as Ulu Apad, indigenous villages, official villages, Bangli Regency government.

\section{Conclusion}

From the above study, it can be concluded as follows: First, the form of sustainable tourism based on environmental wisdom includes (1) the form of policies contained in the vision of tourism village management institutions, (2) the form of the organizational structure of the management institution that collaborates between indigenous people and villagers, and (3) the form of distribution of retribution proceeds determined through the Decree of the Level II Regional Head of Bangli. Second, the implementation of sustainable tourism based on environmental wisdom includes (1) conservation of the physical environment, (2) preservation of the biotic environment (forest), and (3) the development of tourism businesses. Third, the sustainable tourism model based on environmental wisdom is a model of tourism village development with collaboration between local community elements such as Ulu Apad, indigenous villages, official villages, Bangli Regency government.

Acknowledgements. We show gratitude to God, and also for the editorial boards and publishing team of EAI Publisher for the contribution to the process of publishing this paper.

\section{References}

[1] Richards, G.: Cultural tourism: A review of recent research and trends. J. Hosp. Tour. Manag. Vol. 36. pp. 12-21 (2018)

[2] Guccio, C., Mazza, I., Mignosa, A and Rizzo, I.: A round trip on decentralization in the tourism sector. Ann. Tour. Res. Vol. 72. pp. 140-155 (2018)

[3] Azam, M., Alam, M, M and Hafeez, M, H.: Effect of tourism on environmental pollution: Further evidence from Malaysia, Singapore and Thailand. J. Clean. Prod. Vol. 190. pp. 330-338 (2018)

[4] Okafor, L, E., Khalid, U and Then, T.: Common unofficial language, development and 
international tourism. Tour. Manag. Vol. 67.pp. 127-138 (2018)

[5] Wan, S, K and Song, H.: Forecasting turning points in tourism growth. Ann. Tour. Res. Vol. 72. pp. 156-167 (2018)

[6] Kapera, I.: Sustainable tourism development efforts by local governments in Poland. Sustain. Cities Soc. Vol. 40. pp. 581-588 (2018).

[7] Dutt, C, S., Harvey, W, S and Shaw, G.: The missing voices in the perceptions of tourism: The neglect of expatriates. Tour. Manag. Perspect. Vol. 26. pp. 193-202 (2018)

[8] Huber, D., Milne, S and Hyde, K, F.: Constraints and facilitators for senior tourism. Tour. Manag. Perspect. Vol. 27. pp. 55-67 (2018)

[9] Bispo, M. de S.: Tourism as practice. Ann. Tour. Res. Vol. 61. pp. 170-179 (2016)

[10] Suwantoro, G.: Dasar-Dasar Pariwisata. Yogyakarta: Andi Offset (2005)

[11] Arida, N, S.: Meretas Jalan Ekowisata Bali. Denpasar: Udayana University Press (2009)

[12] Dalem, A, A, G, R.: Kearifan Lokal dalam pengelolaan Lingkungan. Denpasar: Udayana University Press. (2009)

[13] Laksmi, A, A, R, S.: Cagar Budaya Bali Menggali Kearifan Lokal dan Model Pelestariannya. Denpasar: Udayana University Press (2011)

[14] Foucault, M.: Power/Knowledge (Kuasa/Pengetahuan). Translatio. Yogyakarta: Bentang Budaya.

[15] Ardika, I, W.: Pariwisata Budaya Berkelnjutan refleksi dan Harapan di tengah Perkembangan Global. Denpasar: Pusaka Budaya dan Pariwisata (2003)

[16] Ardika, I, W.: Pariwisata Budaya Berkelnjutan refleksi dan Harapan di tengah Perkembangan Global. Denpasar: Pustaka Larasan. (2007) 